\section{DÜBLIN}

Technological University Dublin ARROW@TU Dublin

\title{
Wholesomeness and safety aspects of irradiated foods
}

\author{
Rajeev Ravindran \\ Technological University Dublin, rajeev.ravindran@tudublin.ie \\ Amit Jaiswal \\ Technological University Dublin, amit.jaiswal@tudublin.ie
}

Follow this and additional works at: https://arrow.tudublin.ie/schfsehart

Part of the Food Chemistry Commons, and the Nutrition Commons

\section{Recommended Citation}

Rajeev Ravindran, Amit K. Jaiswal, Wholesomeness and safety aspects of irradiated foods, Food Chemistry, Volume 285, 2019, Pages 363-368, ISSN 0308-8146, DOI: 10.1016/j.foodchem.2019.02.002.

This Article is brought to you for free and open access by the School of Food Science and Environmental Health at ARROW@TU Dublin. It has been accepted for inclusion in Articles by an authorized administrator of ARROW@TU Dublin. For more information, please contact arrow.admin@tudublin.ie, aisling.coyne@tudublin.ie, gerard.connolly@tudublin.ie.

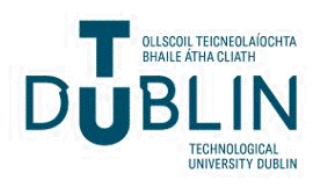


Review

\title{
Wholesomeness and safety aspects of irradiated foods
}

\author{
Rajeev Ravindran, Amit K. Jaiswal* \\ School of Food Science and Environmental Health, College of Sciences and Health, Technological University Dublin, Cathal Brugha Street, Dublin 1, Ireland
}

\section{A R T I C L E I N F O}

\section{Keywords:}

Food irradiation

Wholesomeness

Nutrition

Toxicology

Safe consumption

\begin{abstract}
A B S T R A C T
Food processing techniques are inevitable technological measures that aim to increase and sustain the quality of agricultural products. This is traditionally achieved by the application of heat or exposure to chemicals. Since the advent of X-rays, food scientists have been evaluating the prospect of employing ionising radiations for pest removal, sprouting inhibition and shelf-life extension of food products. Gamma radiation, electron beam and Xrays have emerged as the favoured methods of food irradiation in recent years. Several decades of research have endeavoured to determine the advantage and disadvantage of subjecting food materials to radiation. This has resulted in several international bodies, such as WHO and FAO, certifying that food irradiation is a safe processing method. This review article provides an insight of the various effects of irradiation on food with respect to nutritional quality, shelf-life extension, toxicological aspects, legislation pertaining to food irradiation and global acceptability.
\end{abstract}

\section{Introduction}

Food irradiation is a safe food processing technology that employs ionizing radiation or electron beams for improving food safety. Irradiation of food materials results in prolonging of shelf life and inactivation of microorganisms, insects and delaying of ripening and sprouting in tubers. Food irradiation implements low-energy radiation. The changes brought about by irradiation of food are generally acceptable in terms of appearance and nutritional effects. Countries all over the world have adopted different irradiation measures for a variety of food products. Food irradiation was not a popular concept until recent studies provided evidence of its benefits and safety. Research programmes for food irradiation were initiated all over western Europe in the 1950's. Consequently, the International Project in the field of Food Irradiation (IPFI) was launched in 1970 to examine and verify the effects of radiation on the wholesomeness of food and its influence on nutritional content. The findings of this project were examined by a joint committee formed by the Food and Agriculture Organisation (FAO), International Atomic Energy Agency (IAEA) and World Health Organisation (WHO). This committee concluded that exposing food to an ionising radiation of strength less than $10 \mathrm{kGy}$ did not present any toxicological hazard, nutritional or microbial problems (Diehl, 2002). Consequently, national governments and international agencies set up the International Consultative Group on Food Irradiation (ICFGI) for the exchange of information on food irradiation. In 1997, a group study conducted by FAO, IAEA and WHO examined the results of exposing food to radiation above the recommended dose of $10 \mathrm{kGy}$. It was found that few food samples could tolerate such high doses without loss of sensory qualities. However, irradiating animal feed with radiation doses higher than $70 \mathrm{kGy}$ revealed that the test subjects had no healthrelated problems. It was thus concluded that it is safe to expose food to ionising radiation of any dose, if it is intended to achieve a technological objective and that it does not render the food nutritionally deficient and it can be consumed safely (Organization, 1999). So far over 50 countries have adopted food irradiation as a sanitary and phytosanitary processing method for over 60 foods and food products (Ihsanullah \& Rashid, 2017).

\section{Sources of food irradiation}

The facilities for food irradiation use three sources of radiation viz. gamma radiation, $\mathrm{X}$-rays $(\leq 7.5 \mathrm{MeV}$ in some countries and $\leq 5 \mathrm{MeV}$ in others) and electron beams ( $\leq 10 \mathrm{MeV})$. Gamma radiations are generated using radionuclides such a ${ }^{60} \mathrm{Co}$ and ${ }^{137} \mathrm{Cs}$. The use of ${ }^{137} \mathrm{Cs}$ for food processing purposes is highly discouraged due to the high solubility of the isotope in water. The application of electron beam also has a similar effect on atoms and molecules, such as breakage of double stranded structures (microbial DNA) and the formation of highly reactive free radicals (Lung et al., 2015). X-rays, being penetrative in nature, are extensively used to irradiate food products that have been packaged in boxes. Gamma irradiation is the preferred method of food irradiation due to continual emitting of rays at a predictable rate.

\footnotetext{
* Corresponding author.

E-mail addresses: amit.jaiswal@dit.ie, akjaiswal@outlook.com (A.K. Jaiswal).
} 
Table 1

Dose of radiation typically applied in food industries, associated benefits and products.

\begin{tabular}{|c|c|c|c|}
\hline Benefit & Dose (kGy) & Products & Reference \\
\hline \multicolumn{4}{|l|}{ Low-dose (up to $1 \mathrm{kGy}$ ) } \\
\hline Inhibition of sprouting & $0.05-0.15$ & $\begin{array}{l}\text { Onion, Garlic, Potato, sugar beet, ginger, } \\
\text { carrot }\end{array}$ & Kader (1986), Prakash (2016) \\
\hline Phytosanitation & $0.15-0.5$ & $\begin{array}{l}\text { Cereals, pulses, fruits (fresh and dried), } \\
\text { fish, meat and pork etc. }\end{array}$ & $\begin{array}{l}\text { Al-Kahtani et al. (1998), Cornwell (2013), McDonald et al. (2012), Pillai and } \\
\text { Shayanfar (2017) }\end{array}$ \\
\hline $\begin{array}{l}\text { Delay of physiological changes } \\
\text { such as ripening }\end{array}$ & $0.25-1.0$ & Fresh fruits and vegetables & $\begin{array}{l}\text { Hossain, Parvez, Munshi, Khalil, and Huque (2014), Sea, Rakovski, and Prakash } \\
\text { (2015), Surendranathan and Nair (2013), Yadav and Patel (2014) }\end{array}$ \\
\hline \multicolumn{4}{|l|}{ Medium-dose (1-10 kGy) } \\
\hline Shelf life extension & $1.0-3.0$ & Fish, meat, corn, celery, meat & $\begin{array}{l}\text { Fadhel et al. (2016), Kumar, Gautam, and Sharma (2015), Lefebvre, Thibault, } \\
\text { Charbonneau, and Piette (1994), Prakash, Inthajak, Huibregtse, Caporaso, and } \\
\text { Foley (2000), Yang et al. (2014) }\end{array}$ \\
\hline Disinfection & $1.0-7.0$ & Frozen seafood, poultry and meat & $\begin{array}{l}\text { Javanmard, Rokni, Bokaie, and Shahhosseini (2006), Laycock and Regier (1970), } \\
\text { Patterson (1988) }\end{array}$ \\
\hline Improving the quality of produce & $2.0-7.0$ & $\begin{array}{l}\text { Improving juice yield in fruits, } \\
\text { dehydration of vegetables (decreases } \\
\text { cooking time) }\end{array}$ & Mitchell et al. (1991), Mongpraneet, Abe, and Tsurusaki (2002) \\
\hline \multicolumn{4}{|l|}{ High dose (10-50 kGy) } \\
\hline Industrial sterilisation & $20-40$ & Meat, poultry, seafood & Dionísio, Gomes, and Oetterer (2009) \\
\hline Decontamination of food additives & 30 & Spices, natural gum etc. & SádECká (2007) \\
\hline
\end{tabular}

Electron beam and X-rays are machine-generated and are dependent on parts which can wear out while also being contingent on a constant supply of electricity (Hallman, 2017).

\section{Effects of irradiation on food products}

\subsection{General}

The changes brought about by irradiation in food products are similar to those observed in general food processing, e.g. heating or freezing. The effects of irradiation can affect the nutritional quality and shelf life of food products. Some of the most important changes brought about by food irradiation in nutritional quality, shelf life extension and toxicology of the irradiated foods are further discussed in the following sections. Table 1 provides insight of the dose of radiation typically applied in food industries.

\subsection{Nutritional aspects}

Irradiation is a 'cold' process which does not involve any rise in temperature. Foods that undergo irradiation processes retain their flavours and aroma that would be diminished by other processing methods such as heating. It also avoids reliance on chemical methods, such as fumigation or pesticides, which are used to combat bacteria and other pests. Food irradiation has no effect on the nutritive value of food products and does not affect important macronutrients, such as carbohydrates, proteins and fats, thus leaving the food fresh. The changes imparted to dietary carbohydrates, such as starch, have been extensively studied over years. Recently, Bashir, Swer, Prakash, and Aggarwal (2017) investigated the changes in functional properties of starch and wheat flour after gamma irradiation. They reported that there were no significant changes in the composition or bulk density of the flour. Interestingly, the amylose content in the flour increased by 25 to $36 \%$, depending on the dosage. Furthermore, a decrease in viscosity was observed, accompanied by an increase in water and oil absorption capacity.

Irradiation leads to oxidation, polymerisation, decarboxylation and dehydration in fatty acids and lipids and releases several compounds, depending on the composition. The general mechanism of lipid radiolysis involves primary ionisation, followed by the migration of positive charge towards the carboxylic group. The changes that occur in lipids can be avoided by irradiating at freezing temperatures, and by packaging to eliminate the effects of light and oxygen. An interesting study was conducted by Pereira et al. (2016) on the effects of gamma radiation and electron beam to conserve wild Arenaria montana $\mathrm{L}$ which is an important source of bioactive compounds. Both treatments had a significant effect on the fatty acid content. While the saturated fatty acid and mono unsaturated content increased, a reduction in polyunsaturated fatty acids was observed.

Several researchers have reported the effects of gamma and electron beam radiation on the chemical and antioxidant profiles of numerous food products. Significant changes in sugar, protein, fatty acid and antioxidant activity in Amanita mushrooms were recorded when exposed to electron beam radiation. The apparent increase in protein content of irradiated mushroom was due to the increase in nitrogen atoms caused by the excision of $\mathrm{C}-\mathrm{N}$ bonds or protein unfolding which takes place during the Kjeldahl reaction, translating into higher nutritional content (Fernandes et al., 2015). Treating mushrooms with $2 \mathrm{kGy}$ gamma radiation can lead to reduction in sugar content (Fernandes et al., 2016). Gamma irradiation and electron beam irradiation decrease the antioxidant activity in wild Arenaria montana L (Pereira et al., 2016). Arenaria montana L contains apigenin derivates which are bioactives that exhibit anti-inflammatory and anti-cancer properties (Oliveira et al., 2017).

Milk and dairy products are major sources of vitamins A and E. These food products are generally not suitable for irradiation. However, irradiation of dairy products can be carried out up to $40 \mathrm{kGy}$ without forming any off flavours provided that the temperatures for the procedure are maintained as low as $-78{ }^{\circ} \mathrm{C}$ (Hashisaka, Matches, Batters, Hungate, \& Dong, 1990). Carotene and beta-carotene, the precursors of vitamin A are generally not affected by the irradiation of fruits such as lycium (Wen, Chung, Chou, Lin, \& Hsieh, 2006). However, this may vary according to the type of fruit or vegetable. For example, $50 \%$ loss in beta carotene content occurred when carrots were irradiated using a dosage of $0.1 \mathrm{kGy}$ and stored for 6 months (Hajare, Dhokane, Shashidhar, Sharma, \& Bandekar, 2006).

\subsection{Shelf life extension}

The shelf life of a food product is achieved by inactivating the microbes present in them. Radiation, irrespective of its nature (ionising or non-ionising), causes damage to several components of the cell, including the genetic material. This not only disrupts the cellular function randomly, but also incapacitates the ability of microbes to replicate or regenerate. The effect of radiation on the bacterial DNA is described in detail in Fig. 1. Double strand lesion rarely occurs, due to the 


\section{Irradiation and microbial safety}

Apart from prevention of sprouting, food irradiation kills the inherent bacterial population in fresh, agricultural produce. The decimal reduction value $\left(D_{10}\right)$ is defined as the radiation required to eliminate $90 \%$ of the population under defined conditions.

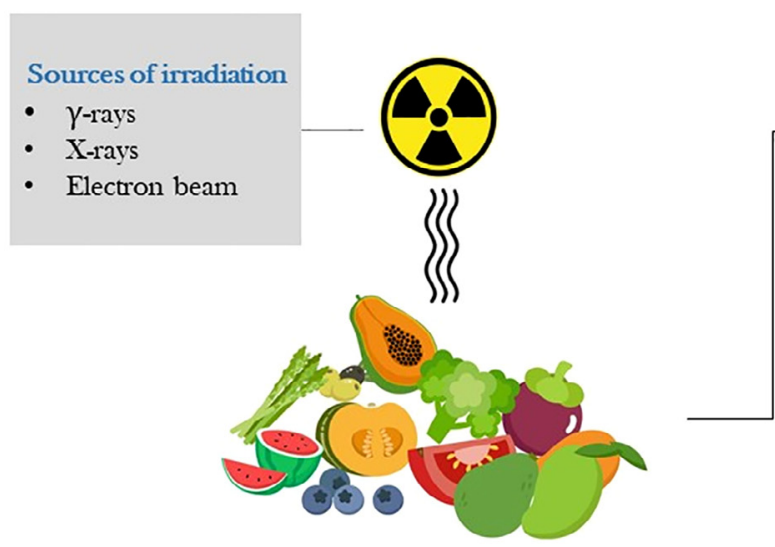

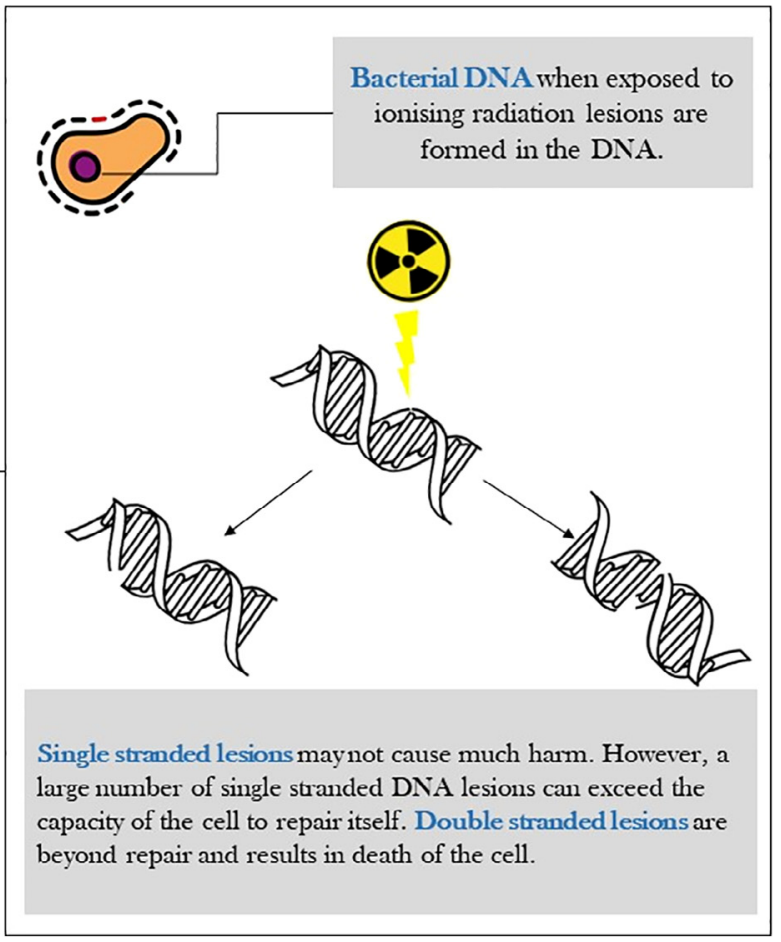

Fig. 1. Mechanism of bacterial decontamination by irradiation. orientation of the DNA, in contrast to single strand lesions (Jaiswal, 2016). Additionally, other components of the cell are also subjected to interactions with ionising radiations. Even with an undisturbed DNA, damaging effects on cellular proteins and membrane may impede the chances of survival of the injured cell. However, certain bacterial species have adapted to resist the changes brought about by irradiation. Deinococcus radiodurans is an example of a bacterial species that can resist radiation up to $30 \mathrm{kGy}$ (Rainey et al., 2005). This bacterial species can survive moderately high doses of radiation due to its highly efficient DNA repair mechanism. $D$. radiodurans can reverse the effects of radiation damage on its DNA by means of an efficient proteome mechanism that facilitates DNA repair, including disintegrated DNA (Krisko \& Radman, 2013). The emergence of multidrug-resistant microorganisms, due to the flaws in chemical treatments, is a concern and this phenomenon has drawn parallels with irradiation. However, irradiated microorganisms are sensitive to treatments involving temperature variations, antimicrobial food components and repeated irradiation (Ehlermann, 2016). With several countries across the world adopting irradiation to treat and preserve food products of various nature, studies of this technology for shelf life extension have accelerated over recent years. In one study carried out by Sirisoontaralak, Suthirak, Papaka, and Vongsawasdi (2017) the authors were able to extend the shelf life of chiffon cake from 3 days to 75 days by irradiating it at a dosage of $4 \mathrm{kGy}$, thus successfully eliminating the need for chemical preservatives.

\subsection{Toxicological aspects}

While the reactive radicals generated by food irradiation result in improved shelf-life, they can also react with chemical components, generating radiolytic products, such as formaldehyde and short chain hydrocarbons (Ravindran \& Jaiswal, 2017). Radiolysis of triglycerides gives rise to 2-alkylcyclobutanones (2-ACBs). The formation of 2-ACBs is represented in Fig. 2. Since these molecules are unique in nature, they have been chosen as markers to identify food products that have been subjected to irradiation. The uniqueness of these compounds has triggered studies for their identification. Meng and Chan (2017) successfully employed a LC-MS/MS system to identify different 2-ACBs formed on irradiation of fatty acids, triglycerides, corn oil, and pork samples with UV-C. Earlier GC-MS was extensively used for their determination (Chan, Ye, \& Leung, 2014).

Several studies have been conducted over the past decade to determine the toxicology and mutagenic effects associated with the consumption of 2-ACBs. These studies have reported that 2-ACBs exhibit no mutagenic or genotoxic effects on mammalian cell lines at low concentrations. However, the consumption of these chemicals at higher doses has resulted in cytotoxicity and damage to the genetic material in rat and human colon cells (Song et al., 2014).

More encouragingly, irradiation can control the formation of nitrosamine and nitrite-related products in cured meat. Nitrates and nitrites are food additives in processed meat which impart colour and flavour. It has been shown that these additives are also potential cancercausing agents (Knekt, Järvinen, Dich, \& Hakulinen, 1999). Irradiating cured meat at sterilisation doses eliminates or decreases the levels of nitrates and nitrites drastically, to maintain the colour and flavour of the meat product. Frying of irradiated bacon results in the meat being free from any nitrates, nitrites or nitrosamines. Furthermore, irradiating bacon at $-40{ }^{\circ} \mathrm{C}$ at a sterilisation dose of $30 \mathrm{kGy}$ reduces the residual nitrite, as well as volatile nitrosamine present. Irradiated bacon, which had $20 \mathrm{ppm}$ of sodium nitrite and $550 \mathrm{ppm}$ of sodium ascorbate, resulted in nitrosamine concentrations that were similar to that of nitritefree bacon (Hui, 2012).

Several studies have been conducted in vitro on the possibility of chromosomal damage that may occur due to the consumption of irradiated foods. George, Chaubey, Sundaram, and Gopal-Ayengar (1976) and Renner (1977), in separate studies, reported increase in polyploidy in bone marrow cells of mice and chinese hamsters fed with radiosterilised diet. However, a study in India was conducted which investigated the chromosome damage in malnourished children after the consumption of fresh, stored and irradiated wheat. In a short span, the chromosomes of the children fed with irradiated wheat showed breaks compared to those supplied with traditional wheat (Bhaskaram \& Sadasivan, 1975). However, this study was criticised due to the small sample size. 


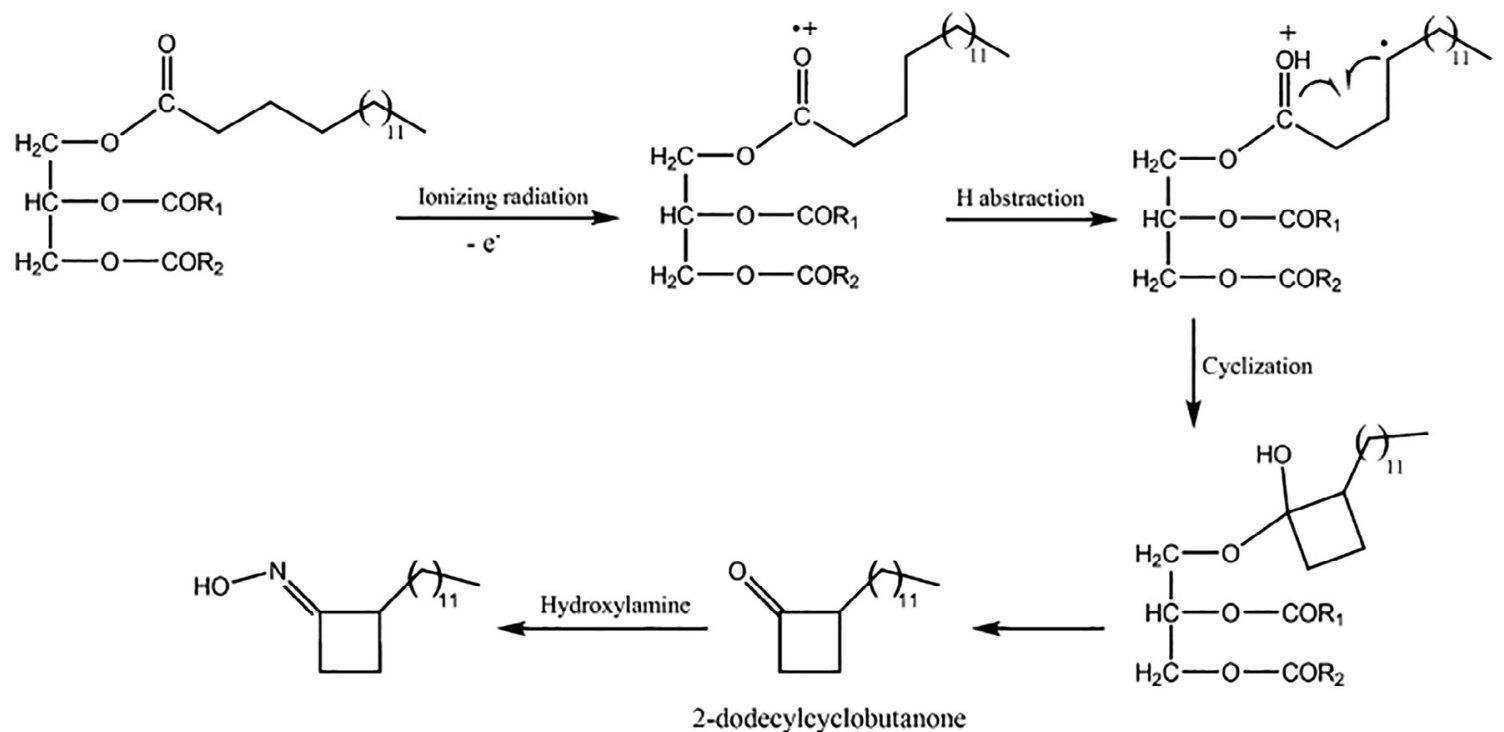

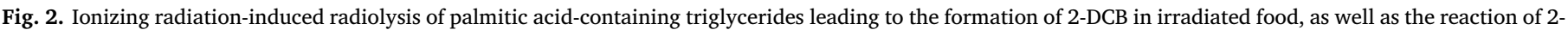
DCB with HA forming a ketoxime (with permission).

\section{Safety aspects of irradiation in food processing}

"Wholesomeness" is a term associated with any food additive, implying that its addition renders the food product microbiologically, nutritionally and toxicologically safe. As explained in the earlier section, not all radiolytic products cause health risks; besides they are consumed at too low concentrations to affect most biological systems. Safety aspects must be considered in close conjunction with toxicological studies of irradiated foods. In a food irradiation facility, the amount of energy or dose absorbed by a food product is determined by a set speed. In a controlled environment the food itself never comes into direct contact with the source of radiation. Exposing food to higher doses of radiation can lead to some of the components becoming radioactive. In a study involving ground beef, induced radioactivity was observed after exposure to x-rays produced by $7.5 \mathrm{MeV}$ electrons. However, the induced activity was significantly lower than the natural radioactivity in food. This makes the risk involved of the intake of irradiated foods by individuals trivial (Grégoire et al., 2003). Another study conducted by the International Atomic Energy Agency (IAEA) concluded that energy beams emitted from food irradiated by doses below $60 \mathrm{kGy}$, with gamma rays from cobalt- 60 and caesium 137, were less than $5 \mathrm{MeV}$ in strength and can be considered insignificant (Agency, 2002).

\section{Public acceptability of irradiated foods}

The US FDA, in their website, claims that irradiated foods are safe for consumption and that they are devoid of any disease-causing microorganism, parasites and pests. Food irradiation does not make the food product radioactive. Nutrition losses pertaining to food irradiation are akin to those that occur while cooking or freezing. The outbreak of E. coli $0157: \mathrm{H7}$ in the west coast of the US, caused due to consumption of undercooked hamburgers, which resulted in the hospitalisation and death of several children, led to the first public interest in the utilisation of irradiation to sterilise food products (Loharanu, 1997). Irradiated foods are gaining acceptance in society at a rapid pace, due to increased public understanding of the process. Consumers have purchased irradiated foods according to their availability during recent times because of their satisfaction with the quality and safety of the product. Irradiation technology has enabled the import of fruits and vegetables from countries into the US that were once prohibited due to the fear of importing pests along with the produce. Certain tropical produce from
Asian countries, such as speciality mangoes, cannot withstand phytosanitary procedures such as hot water treatment and need to be irradiated to ensure the elimination of pests.

Education of consumers is key to food irradiation gaining public acceptance. Providing a small amount of accurate information encourages the consumer to choose irradiated food over conventionally treated food. Several market research studies have reported that $80-90 \%$ of consumers will buy irradiated food products after being aware of the safety and benefits of food irradiation. A study conducted by the University of California in 1995-96 found that interest in buying irradiated food among consumers was increased from $57 \%$ to $82 \%$ by just viewing a $10 \mathrm{~min}$ video on food irradiation (Eustice \& Bruhn, 2006). According to reports based on a convention held in Bangkok on the acceptance and market development of irradiated foods in Asia in 1998, Pacific countries, such as Bangladesh and Thailand, have already accepted the benefits of irradiated foods. In fact, Thailand hosted a flourishing market for irradiated food products. The People's Republic of China approved irradiation of food (by classes) in terms of the nature of the food, such as fruits and vegetables, meat and poultry, spices, cooked meat, dried fruits and nuts and dehydrated vegetables. Other nations, such as Sri Lanka, Pakistan, the Philippines and South Korea took steps toward setting up irradiation facilities over a span of two years (Joint, 2001).

\section{Legislation pertaining to food irradiation}

In the US, issues pertaining to irradiation of food products are governed by the Food and Drug Administration (FDA). According to the Food Additives Amendment to the Federal Food, Drug and Cosmetic Act of 1958, irradiation falls under the category of an 'additive'. The Food Additive Amendment states that food may be considered adulterated if irradiated intentionally unless the irradiation is carried out by abiding to the regulations that prescribe safe use. The amendment pertaining to irradiation deals with safety issues, such as radiological safety, toxicological safety, microbial safety and nutritional adequacy. Several studies have repeatedly confirmed that doses of irradiation used for sterilisation of food products are too low to induce any detectable radioactivity (Grégoire et al., 2003). The effects of irradiation on the degeneration of microbes, changes in nutritional aspects and the formation of radiolytic products due to food irradiation have been discussed in detail in earlier sections.

The FDA recommends food irradiation as a safe practice and has 
issued approvals for the use of irradiation. Accordingly, fruits and vegetables can be exposed to doses not higher than $1 \mathrm{kGy}$ to control or remove insects, pests and other arthropods and inhibit sprouting and ripening so that the freshness is maintained. Furthermore, irradiation of poultry should not exceed $3 \mathrm{kGy}$ to control food-borne pathogens. For refrigerated and frozen meat, the recommended dosages of irradiation to remove pathogens are $4.5 \mathrm{kGy}$ and $7.0 \mathrm{kGy}$ respectively. Dehydrated enzymes can be treated with dosages up to $10 \mathrm{kGy}$ to control microorganisms. Spices and seasonings may undergo irradiation with doses that do not exceed $30 \mathrm{kGy}$ to control microorganisms.

Under labelling requirements, the FDA mandates food manufacturers to inform the consumers if a food product has been irradiated because the process may bring changes to the product. Accordingly, irradiated food products must bear the radura symbol and should be labelled "treated with radiation" or "treated by radiation". However, foods that have added ingredients that have been irradiated need no special labelling.

The European Union has established strict legislation in relation to the control of irradiated foods. The European Parliament passed the framework directive 1999/2/EC which deals with all basic aspects of food that has been treated with ionising radiation. The EU legislation makes it necessary for any food item that has undergone irradiation (or has irradiated ingredients) to be labelled as 'irradiated' or 'treated by ionising radiation' so that consumers can make an informed choice. Furthermore, each EU member state is supposed to forward the results of checks performed at irradiation facilities. Validated and standardised methods of analysis have been approved by the EU that the member states are supposed to implement and follow. The second directive 1999/3/EC instructs member states on the foods and food ingredients that can be subjected to ionising radiation. Accordingly, only three food groups, namely dried aromatic herbs, spices and vegetable seasonings can be irradiated and distributed in EU member states (Parliament, 1999).

\section{Concluding remarks and future trends}

Food irradiation, in recent years, has emerged as a viable processing technique with more and more countries adopting this method to disinfect and exercise pest control in agricultural produce. The scientific community has shown a rejuvenated interest in studying the chemistry of radiolytic product formation due to irradiation of different nutrients in food. Developing nations in south east Asia and the EU are welcoming the idea of irradiating food products for shelf-life extension and phytosanitation. However, all is not the same with the common consumer, who views irradiation as a hazardous method of food processing. Nonetheless, with governments exercising more confidence in irradiated food products, this technology is gaining acceptability in modern society. Food irradiation and its effects on the wholesomeness of food can be concluded by the following points:

- Food irradiation, although being a cost-intensive process which requires the handling of radioactive minerals, has been found to be a practical form of technology to ensure food safety.

- Not all foods are fit to be irradiated. Certain nutrients, e.g. vitamins, are to an extent affected by food irradiation. However, meat irradiation has been studied on a wide scale and few nutritional deficiencies have been reported.

- Shelf life extension by food irradiation is superior to thermal processing and avoids the need for artificial preservatives, thus maintaining the nutritional value of foods.

- As was believed earlier, there is no concrete proof to support the idea that radiolytic products can cause cancer or other degenerative diseases.

- People associate ionising radiation with cancer and consider irradiated food as equally hazardous. This is a misconception that must be eradicated by proper education.
- All the international agencies, such as WHO, FDA and IAEA, have approved food irradiation as a safe and effective technique to ensure food safety.

Recent trends in food irradiation research have seen an increase in the study of radiolytic products formed after the irradiation of several foods. Although this type of research may be motivated by a certain degree of scepticism, no study has reported the generation of toxic chemicals because of radiolysis. Furthermore, old techniques of analysis are giving way to advanced measures that can analyse the formation of several radiolytic products. The radiolytic products of triglycerides (2ACB's in particular) have been labelled as carcinogens over past decades. However, this claim is being refuted by new research that suggested that their consumption does not cause any health risks.

\section{Conflict of interest}

The authors declare no conflict of interest.

\section{References}

Agency, I. A. E. (2002). Natural and induced radioactivity in food. Vienna: International Atomic Energy Agency.

Al-Kahtani, H. A., Abu-Tarboush, H. M., Al-Dryhim, Y. N., Ahmed, M. A., Bajaber, A. S. Adam, E.-S. E., \& El-Mojaddidi, M. A. (1998). Irradiation of dates: Insect disinfestation, microbial and chemical assessments, and use of thermoluminescence technique. Radiation Physics and Chemistry, 53(2), 181-187.

Bashir, K., Swer, T. L., Prakash, K. S., \& Aggarwal, M. (2017). Physico-chemical and functional properties of gamma irradiated whole wheat flour and starch. LWT - Food Science and Technology, 76, 131-139.

Bhaskaram, C., \& Sadasivan, G. (1975). Effects of feeding irradiated wheat to malnourished children. American Journal of Clinical Nutrition, 28(2), 130-135.

Chan, W., Ye, Y., \& Leung, E. M. K. (2014). Rapid identification of $\gamma$-irradiated food by direct solvent extraction and liquid chromatography-tandem mass spectrometric analysis of 2-dodecylcyclobutanone: Application in surveillance of irradiated food. Food Chemistry, 161, 312-316.

Cornwell, P. B. (2013). The entomology of radiation disinfestation of grain: A collection of original research papers. Elsevier.

Diehl, J. F. (2002). Food irradiation—past, present and future. Radiation Physics and Chemistry, 63(3), 211-215.

Dionísio, A. P., Gomes, R. T., \& Oetterer, M. (2009). Ionizing radiation effects on food vitamins: A review. Brazilian Archives of Biology and Technology, 52, 1267-1278.

Ehlermann, D. A. E. (2016). Wholesomeness of irradiated food. Radiation Physics and Chemistry, 129, 24-29.

Eustice, R. F., \& Bruhn, C. M. (2006). Consumer acceptance and marketing of irradiated foods. Food Irradiation Research and Technology, 63-83.

Fadhel, Y. B., Leroy, V., Dussault, D., St-Yves, F., Lauzon, M., Salmieri, S., ... Lacroix, M. (2016). Combined effects of marinating and $\gamma$-irradiation in ensuring safety, protection of nutritional value and increase in shelf-life of ready-to-cook meat for immunocompromised patients. Meat Science, 118, 43-51.

Fernandes, Â., Barreira, J. C. M., Antonio, A. L., Oliveira, M. B. P. P., Martins, A., \& Ferreira, I. C. F. R. (2016). Extended use of gamma irradiation in wild mushrooms conservation: Validation of $2 \mathrm{kGy}$ dose to preserve their chemical characteristics. LWT - Food Science and Technology, 67, 99-105.

Fernandes, Â., Barreira, J. C. M., Antonio, A. L., Rafalski, A., Oliveira, M. B. P. P., Martins, A., \& Ferreira, I. C. F. R. (2015). How does electron beam irradiation dose affect the chemical and antioxidant profiles of wild dried Amanita mushrooms? Food Chemistry, 182, 309-315.

George, K. P., Chaubey, R. C., Sundaram, K., \& Gopal-Ayengar, A. R. (1976). Frequency of polyploid cells in the bone marrow of rats fed irradiated wheat. Food and Cosmetics Toxicology, 14(4), 289-291.

Grégoire, O., Cleland, M. R., Mittendorfer, J., Dababneh, S., Ehlermann, D. A. E., Fan, X., Thayer, D. W. (2003). Radiological safety of food irradiation with high energy Xrays: Theoretical expectations and experimental evidence. Radiation Physics and Chemistry, 67(2), 169-183.

Hajare, S. N., Dhokane, V. S., Shashidhar, R., Sharma, A., \& Bandekar, J. R. (2006). Radiation processing of minimally processed carrot (Daucus carota) and cucumber (Cucumis sativus) to ensure safety: Effect on nutritional and sensory quality. Journal of Food Science, 71(3).

Hallman, G. J. (2017). Process control in phytosanitary irradiation of fresh fruits and vegetables as a model for other phytosanitary treatment processes. Food Control, 72 , 372-377.

Hashisaka, A., Matches, J., Batters, Y., Hungate, F., \& Dong, F. (1990). Effects of gamma irradiation at- $78{ }^{\circ} \mathrm{C}$ on microbial populations in dairy products. Journal of Food Science, 55(5), 1284-1289.

Hossain, F., Parvez, A. K., Munshi, M. K., Khalil, I., \& Huque, R. (2014). Post-harvest treatments of radiation and chemical on organoleptic and biochemical properties of mango (Mangifera indica) in relation to delay. American-Eurasian Journal of Agricultural and Environmental Sciences, 14(6), 555-564. 
Hui, Y. H. (2012). Handbook of meat and meat processing. Boca Raton, Florida: CRC Press. Ihsanullah, I., \& Rashid, A. (2017). Current activities in food irradiation as a sanitary and phytosanitary treatment in the Asia and the Pacific Region and a comparison with advanced countries. Food Control, 72, 345-359.

Jaiswal, A. K. (2016). Food processing technologies: Impact on product attributes. Boca Raton, Florida: CRC Press.

Javanmard, M., Rokni, N., Bokaie, S., \& Shahhosseini, G. (2006). Effects of gamma irradiation and frozen storage on microbial, chemical and sensory quality of chicken meat in Iran. Food Control, 17(6), 469-473.

Joint, F. (2001). Consumer acceptance and market development of irradiated food in Asia and the Pacific. Proceedings of a final research co-ordination meeting. In): Joint FAO/IAEA Division of Nuclear Techniques in Food and Agriculture.

Kader, A. A. (1986). Potential applications of ionizing radiation in postharvest handling of fresh fruits and vegetables. Food Technology, 40(6), 117-121.

Knekt, P., Järvinen, R., Dich, J., \& Hakulinen, T. (1999). Risk of colorectal and other gastro-intestinal cancers after exposure to nitrate, nitrite and N-nitroso compounds: A follow-up study. International Journal of Cancer, 80(6), 852-856.

Krisko, A., \& Radman, M. (2013). Biology of extreme radiation resistance: The way of deinococcus radiodurans. Cold Spring Harbor Perspectives in Biology, 5(7).

Kumar, S., Gautam, S., \& Sharma, A. (2015). Hurdle technology including chlorination, blanching, packaging and irradiation to ensure safety and extend shelf life of shelled sweet corn kernels. Journal of Food Processing and Preservation, 39(6), 2340-2347.

Laycock, A., \& Regier, L. (1970). The effect of gamma irradiation on the microbial spoilage patterns on fish, in relation to initial quality. Preservation of Fish by Irradiation, 13-25.

Lefebvre, N., Thibault, C., Charbonneau, R., \& Piette, J.-P. (1994). Improvement of shelflife and wholesomeness of ground beef by irradiation-2. Chemical analysis and sensory evaluation. Meat Science, 36(3), 371-380.

Loharanu, P. (1997). Consumer Acceptance of Irradiated Food. A Gloval Survey. Memorias Seminario Nacional Aceptacion y comercio de Alimentos Irradiados Ed. Emilia Bustos. Toluca, Mex, México.

Lung, H.-M., Cheng, Y.-C., Chang, Y.-H., Huang, H.-W., Yang, B. B., \& Wang, C.-Y. (2015). Microbial decontamination of food by electron beam irradiation. Trends in Food Science and Technology, 44(1), 66-78.

McDonald, H., McCulloch, M., Caporaso, F., Winborne, I., Oubichon, M., Rakovski, C., \& Prakash, A. (2012). Commercial scale irradiation for insect disinfestation preserves peach quality. Radiation Physics and Chemistry, 81(6), 697-704.

Meng, X., \& Chan, W. (2017). Determination of 2-alkylcyclobutanones in ultraviolet lightirradiated fatty acids, triglycerides, corn oil, and pork samples: Identifying a new source of 2-alkylcyclobutanones. Food Chemistry, 217, 352-359.

Mitchell, G. E., Isaacs, A. R., Williams, D. J., McLauchlan, R. L., Nottingham, S. M., \& Hammerton, K. (1991). Low dose irradiation influence on yield and quality of fruit juice. Journal of Food Science, 56(6), 1628-1631.

Mongpraneet, S., Abe, T., \& Tsurusaki, T. (2002). Accelerated drying of welsh onion by far infrared radiation under vacuum conditions. Journal of Food Engineering, 55(2), 147-156.

Oliveira, F. S., Ribeiro, A., Barros, L., Calhelha, R. C., Barreira, J. C. M., Junior, B. D., ... Ferreira, I. C. F. R. (2017). Evaluation of Arenaria montana L. hydroethanolic extract as a chemopreventive food ingredient: A case study focusing a dairy product (yogurt). Journal of Functional Foods, 38, 214-220.
Organization, W. H. (1999). High-dose irradiation: Wholesomeness of food irradiatied with doses above $10 \mathrm{kGy}$. World Health Organization.

Parliament, E. (1999). "Framework Directive 1999/2/EC.".

Patterson, M. (1988). Sensitivity of bacteria to irradiation on poultry meat under various atmospheres. Letters in Applied Microbiology, 7(3), 55-58.

Pereira, E., Barros, L., Barreira, J. C. M., Carvalho, A. M., Antonio, A. L., \& Ferreira, I. C. F. R. (2016). Electron beam and gamma irradiation as feasible conservation technologies for wild Arenaria montana L.: Effects on chemical and antioxidant parameters. Innovative Food Science and Emerging Technologies, 36, 269-276.

Pillai, S. D., \& Shayanfar, S. (2017). Electron beam technology and other irradiation technology applications in the food industry. Topics in Current Chemistry, 375(1), 6.

Prakash, A. (2016). Particular applications of food irradiation fresh produce. Radiation Physics and Chemistry, 129, 50-52.

Prakash, A., Inthajak, P., Huibregtse, H., Caporaso, F., \& Foley, D. (2000). Effects of lowdose gamma irradiation and conventional treatments on shelf life and quality characteristics of diced celery. Journal of Food Science, 65(6), 1070-1075.

Rainey, F. A., Ray, K., Ferreira, M., Gatz, B. Z., Nobre, M. F., Bagaley, D., ... Shank, N. C. (2005). Extensive diversity of ionizing-radiation-resistant bacteria recovered from Sonoran Desert soil and description of nine new species of the genus Deinococcus obtained from a single soil sample. Applied and Environmental Microbiology, 71(9), 5225-5235.

Ravindran, R., \& Jaiswal, A. K. (2017). Toxicological aspects of irradiated foods. In C. F. R. Ferreira, A. L. Antonio, \& S. C. Verde (Eds.). Food irradiation technologies: Concepts, applications and outcomes (pp. 337-351). Cambridge, UK: The Royal Society of Chemistry.

Renner, H. W. (1977). Chromosome studies on bone marrow cells of Chinese hamsters fed a radiosterilized diet. Toxicology, 8(2), 213-222.

SádECká, J. (2007). Irradiation of spices-a review. Czech Journal of Food Science, 25(5), 231-242.

Sea, S., Rakovski, C., \& Prakash, A. (2015). Ripening quality of 'Bartlett'pears (Pyrus communis L.) subjected to phytosanitary $\mathrm{x}$-ray irradiation treatment followed by simulated retail display. HortScience, 50(2), 279-287.

Sirisoontaralak, P., Suthirak, P., Papaka, K., \& Vongsawasdi, P. (2017). Development of shelf stable chiffon cake using gamma irradiation. LWT - Food Science and Technology, $75,78-84$.

Song, B.-S., Choi, S.-J., Jin, Y.-B., Park, J.-H., Kim, J.-K., Byun, E.-B., ... Marchioni, E. (2014). A critical review on toxicological safety of 2-alkylcyclobutanones. Radiation Physics and Chemistry, 103, 188-193.

Surendranathan, K., \& Nair, P. (2013). Carbohydrate metabolism in ripening banana and its alteration on gamma irradiation in relation to delay in ripening. Journal of the Indian Institute of Science, 62(8), 63.

Wen, H.-W., Chung, H.-P., Chou, F.-I., Lin, I. H., \& Hsieh, P.-C. (2006). Effect of gamma irradiation on microbial decontamination, and chemical and sensory characteristic of lycium fruit. Radiation Physics and Chemistry, 75(5), 596-603.

Yadav, M., \& Patel, N. (2014). Optimization of irradiation and storage temperature for delaying ripening process and maintaining quality of Alphonso mango fruit (Mangifera indica L.). African Journal of Agricultural Research, 9(5), 562-571.

Yang, Z., Wang, H., Wang, W., Qi, W., Yue, L., \& Ye, Q. (2014). Effect of $10 \mathrm{MeV}$ E-beam irradiation combined with vacuum-packaging on the shelf life of Atlantic salmon fillets during storage at $4^{\circ} \mathrm{C}$. Food Chemistry, 145, 535-541. 